\title{
Nitrogen bound to humic matter of terrestrial origin - a nitrogen pool for coastal phytoplankton?
}

\author{
Per Carlsson, Ana Zuleika Segatto, Edna Granéli
}

Dept of Marine Ecology, PO Box 124, S-221 00 Lund, Sweden

\begin{abstract}
The effects of additions of river isolated humic compounds on biomass formation and primary production of a natural phytoplankton community were compared with the effects of additions of nitrate or phosphate in a batch culture experiment lasting for $10 \mathrm{~d}$ during late summer. Mesozooplankton $(>150 \mu \mathrm{m})$ were excluded in the experiment, but micrograzers such as heterotrophic nanoflagellates, ciliates and copepod nauplii were present. The humic substances were isolated from river water using a macroporous resin (XAD-8). Trace metals, iron and vitamins were added in order to avoid growth limitation caused by these compounds. Phytoplankton biomass and primary production became significantly higher in treatments where nitrate or humic substances were added than in control flasks. Bacterial numbers became significantly higher in the treatments where humic substances were added compared with controls. Ammonium concentrations became elevated in the treatments where nitrate or humic substances were added. It seems likely that humic substances were utilized by bacteria both as a carbon and a nitrogen source and that nitrogen was incorporated in bacteria and later regenerated as inorganic nitrogen due to the activity of bacterial grazers and other grazers of higher trophic levels. We suggest that this is the mechanism by which nitrogen in humic substances becomes available for coastal phytoplankton communities.
\end{abstract}

\section{INTRODUCTION}

Humic substances (HS) leaking from soils are transported to coastal waters by rivers. The amount of rivertransported HS entering coastal waters can be large in areas where the drainage area is dominated by forest (Andersson et al. 1991). In addition to the autochthonously produced dissolved organic matter (DOM), there is therefore a considerable addition of allochthonous DOM in the form of river-borne humic compounds to these coastal areas. The HS that enter coastal waters presumably affect the plankton communities in several ways. Due to the chelating abilities of HS, essential trace metals could be made available to the phytoplankton (Prakash 1971, Prakash et al. 1973) and toxic metals may be chelated and thus rendered non-toxic to the phytoplankton (Barber 1973, Toledo et al. 1982). HS also reduce light penetration which may decrease primary production (Jones 1992).

HS constitute the largest fraction of the dissolved organic matter (DOM) in most natural waters (Thur- man 1985). HS are considered to be relatively resistant to bacterial degradation (Fenchel \& Blackburn 1979, Geller 1983), and only low-molecular weight DOM produced by phytoplankton is believed to be used by bacteria as a carbon source (Larsson \& Hagström 1979 , Chróst et al. 1989, Vadstein et al. 1989).

However, HS derived from allochthonous sources have been shown to support bacterial growth in freshwater systems (Tranvik 1988, Moran \& Hodson 1990) and are therefore presumably able to enter the microbial loop in coastal waters to some extent.

It is possible that outflow of HS from land-based sources is important for phytoplankton growth in coastal waters, since it has often been observed that extensive outflow of nutrients and organic compounds in rivers has been followed by intensive growth of dinoflagellates, promoting phytoplankton blooms such as 'red tides' (Paerl 1988).

As HS contain some nitrogen ( 3 to $6 \%$; Rashid 1985) these compounds could be a potential nutrient source for phytoplankton. Granéli et al. (1985) have suggested 
that nitrogen bound to HS could be directly available to at least some algal groups such as dinoflagellates. Carlsson \& Granéli (1993) have also found that commercially available HS extracted from soil increased phytoplankton biomass formation in microcosm experiments with coastal water containing natural phytoplankton communities.

In this paper we investigate how HS isolated from river water affect biomass accumulation, growth rates and primary production of a natural autumn plankton community from coastal waters containing bacteria, ciliates, heterotrophic/autotrophic flagellates and phytoplankton. The effects of initial HS addition are compared with additions of phosphate, nitrate and an initial addition of HS followed by a later addition of phosphate.

\section{MATERIALS AND METHODS}

A natural phytoplankton community was collected with a plastic bucket from a depth of 0 to $0.5 \mathrm{~m}$ in the Gullmar Fjord on the Swedish west coast on 14 August 1991, and filtered through a $150 \mu \mathrm{m}$ net in order to remove large grazers such as copepods. The water was then poured into $4.5 \mathrm{l}$ Bibby Blue Pyrex flasks that had been acid soaked (10\% HCl) for $24 \mathrm{~h}$ and then thoroughly rinsed with distilled water. The glass flasks were immersed in a pool which was kept at the in situ temperature $\left(15\right.$ to $16^{\circ} \mathrm{C}$ ) by through flow of surface water from the nearby sea. The system was exposed to natural light conditions $\left(60\right.$ to $330 \mu \mathrm{E} \mathrm{m}^{-2} \mathrm{~s}^{-1}$ during the early afternoon when primary production measurements were made). Some air was left in the flasks and they were able to float in a circular current, created by the inflowing seawater, in which the flasks gently moved around. The motion of the flasks prevented the phytoplankton cells from sedimenting.

The experiment consisted of 20 flasks with the following treatments: 4 controls (C) without macronutrient additions, 4 flasks with additions of $\mathrm{K}_{2} \mathrm{HPO}_{4}$ to give a final $\mathrm{P}$ concentration of $5 \mu \mathrm{mol})^{-1}(+\mathrm{P}), 4$ flasks with additions of $\mathrm{NaNO}_{3}$ to give a final $\mathrm{N}$ concentration of $30 \mu \mathrm{mol} \mathrm{l}^{-1}(+\mathrm{N})$, and 8 flasks with an initial addition of HS that gave an HS concentration of $4.3 \mathrm{mg} \mathrm{l}^{-1}$ (measured as dissolved organic carbon, DOC). Four of the flasks receiving the initial humic addition were designated $+\mathrm{H}$. On Day $6, \mathrm{~K}_{2} \mathrm{HPO}_{4}$ was added to the remaining 4 flasks to increase the $\mathrm{P}$ concentration by $5 \mu \mathrm{mol}$ $1^{-1}$ (+PH flasks).

The initial water had a salinity of $18.0 \%$ and the initial nutrient concentrations were as follows: $\mathrm{NO}_{3}^{-}$: $<0.01 \mu \mathrm{mol} \mathrm{l}^{-1} ; \mathrm{NH}_{4}^{+}: 1.6 \mu \mathrm{mol} \mathrm{l}{ }^{-1} ; \mathrm{PO}_{4}^{3-}: 0.1 \mu \mathrm{mol} \mathrm{l}{ }^{-1}$; Si: $2.0 \mu \mathrm{mol} \mathrm{l}^{-1}$. Si was added to all flasks $\left(20 \mu \mathrm{mol} l^{-1}\right.$ as $\mathrm{Na}_{2} \mathrm{O}_{3} \mathrm{Si} \cdot 5 \mathrm{H}_{2} \mathrm{O}$ ). Trace metals, iron and EDTA were added to all flasks corresponding to $5 \%$ of the culture medium ' $f$ ' described by Guillard \& Ryther (1962) and vitamins ( $B_{12}$, biotin and thiamin) according to Schöne \& Schöne (1982) in order to prevent growth limitation caused by lack of these compounds.

The HS we used were isolated from the River Fylleån in the county of Halland, Sweden. The separation and concentration of HS were carried out using the method described by Thurman \& Malcolm (1981) and Petersen et al. (1987). Water from Fylleån was acidified to pH 1.8 with sulphuric acid and filtered through $50 \mu \mathrm{m}$ and $1 \mu \mathrm{m}$ macrovolume filters (Brunswick Technetics Filterite). The filtered water was then passed through an XAD-8 resin (Amberlite) in a glass column at a rate of $100 \mathrm{ml} \mathrm{min}^{-1}$. By definition, aquatic humus is the organic material that adheres to a macroporous resin (such as XAD-8) at pH 2 (Thurman 1985). The humic material that adhered to the resin was then desorbed by back-flusining the column with 2.5 bed volumes of $0.1 \mathrm{~mol}^{-1} \mathrm{NaOH}$ and immediately acidified. The HS were then passed through a cation exchange resin (MSC-1) to remove sodium and the $\mathrm{pH}$ was adjusted to 7.0 .

Analysis of total nitrogen in the HS, using the method described by Solórzano \& Sharp (1980), showed that it contained $1.9 \% \mathrm{~N}$. The addition of $4.3 \mathrm{mg} \mathrm{l}^{-1}$ of $\mathrm{HS}$ to the flasks was thus equivalent to a final concentration of $5.7 \mu \mathrm{mol} \mathrm{l}^{-1} \mathrm{~N}$ (excluding the initial nitrogen content of the seawater).

The flasks were sampled daily. Before sampling, the flasks were gently rotated to make sure that the water was thoroughly mixed. Daily measurements of in vivo chlorophyll a were made with a Turner 112 filter fluorometer. When humic acid was added to the flasks, the fluorescence reading on the instrument increased by approximately $10 \%$. This elevated fluorescence was compensated for by subtracting the initial increase from all measurements in flasks to which humic acid was added. Since the weak yellow-brown colour appeared to decrease somewhat in the humic acid flasks during the experiments, probably due to photooxidation of HS (see e.g. Amador et al. 1989 or Kieber et al. 1990), the final in vivo chlorophyll a measurements in the humic acid treatments may therefore be slightly underestimated. The Pyrex flasks we used were to some extent permeable to UV-radiation [they permitted approximately $20 \%$ of UV-B radiation to pass according to measurements made with a Model 742 spectroradiometer (Optronics Lab.), interfaced with a Hewlett Packard 85 computer].

The in vivo fluorescence measurements of chlorophyll a were transformed to absolute chlorophyll a values after spectrophotometric analysis of extracted chlorophyll a on the initial day and Day 5 of the experiment, using the method of Jeffrey \& Humphrey (1975). 
Primary production was measured as ${ }^{14} \mathrm{C}$-uptake using the method of Ertebjerg-Nielsen \& Bresta (1984). The incubation time was $2 \mathrm{~h}$ between 12:00 and 14:00 h and we used $25 \mathrm{ml}$ glass flasks to which $2 \mu \mathrm{Ci}$ of radioactive $\mathrm{NaH}^{14} \mathrm{CO}_{3}$ was added. The flasks were incubated at $0.5 \mathrm{~m}$ depth in the pool. Light measurements were carried out with a QSL-100 spherical quantameter (Biospherical Instruments, Inc.) and varied between 60 and $330 \mu \mathrm{E} \mathrm{m}^{-2} \mathrm{~s}^{-1}$ during the incubations, depending on the degree of cloudiness. Primary production was calculated as $\mathrm{mg} \mathrm{C} \mathrm{m}^{-3} \mathrm{~h}^{-1}$ (dark flask values were subtracted from light flask values)

Alkaline phosphatase activity (APA) was measured using the method described by Petterson (1979) in order to detect phosphate deficiency. Nutrients $\left(\mathrm{NO}_{3}{ }^{-}, \mathrm{NH}_{4}{ }^{+}\right.$. $\mathrm{PO}_{4}{ }^{3-}$ and $\mathrm{SiO}_{2}$ ) were analysed using standard procedures for seawater (UNESCO 1983). $\mathrm{NO}_{3}{ }^{-}, \mathrm{PO}_{4}{ }^{3-}$ and $\mathrm{SiO}_{2}$ were analyzed with an autoanalyzer (TRAACS) and $\mathrm{NH}_{4}{ }^{+}$was analyzed by the manual method.

Phytoplankton samples were preserved with acidified Lugol's solution and cell counting was performed with a Nikon Diaphot inverted microscope using the method described by Utermöhl (1958). Cell counting was carried out on 3 occasions during the experiment. At least 50, but often more than 400, cells were counted for each phytoplankton species/group (depending on the abundance in the samples), giving standard deviations of $\pm 28 \%$ or $\pm 10 \%$ respectively. The dimensions of at least 10 cells of each phytoplankton species/group were measured for calculation of plasma volumes of diatoms and cell volumes of other species, following stereometric formulas in Edler (1979) and cell carbon was then calculated using conversion factors of 0.13 for dinoflagellates (Smetacek 1975) and 0.11 for all other species (Strathmann 1967).

Bacteria counting was performed using the fluorochrome DAPI and a Nikon Optiphot epifluorescence microscope equipped with an excitation filter $(365 \mathrm{~nm})$, barrier filter $(400 \mathrm{~nm})$ and dichroic mirror (400 nm), and using the method described by Porter \& Feig (1980)

DOC was measured with a carbon analyzer (Shimadzu TOC-5000) after automatic acidification to remove inorganic carbon.

\section{RESULTS}

\section{Nutrients}

The initial concentrations of nutrients were low in the water used for the experiment (Fig, 1), except for silicate $\left(2.0 \mu \mathrm{mol} \mathrm{l^{-1 }}\right)$ and ammonium $\left(1.7 \mu \mathrm{mol} \mathrm{l}^{-1}\right)$. The ratio of inorganic fractions of nitrogen (nitrate + nitrite and ammonium) to phosphate was approximately
16:1 suggesting that these occurred in suitable proportions for algal growth. The concentrations of nitrogen and phosphorus were, however, limited and were only sufficient to support the formation of approximately $5 \mu \mathrm{g}$ $\mathrm{l}^{-1}$ of chlorophyll $a$ in the control flasks (Fig. 2). The ammonium concentrations initially decreased rapidly (from 1.6 to $0.2 \mu \mathrm{mol} \mathrm{l}^{-1}$ ) between Day 1 and 3 due to algal uptake, but started to increase again in all treatments after Day 3 and reached the highest values between Day 5 and 7 in $+\mathrm{N},+\mathrm{H}$ and $+\mathrm{PH}$ flasks (approximately $0.4 \mu \mathrm{mol} \mathrm{l}^{-1}$ ). The ammonium concentrations were significantly higher in the $+\mathrm{H}$ and $+\mathrm{PH}$ treatments on Day 7 than in the controls ( $p<0.05$, Mann-Whitney $U$-test). Nitrate concentrations increased approximately from undetectable to $0.1 \mu \mathrm{mol} \mathrm{l}^{-1}$ between Days 3 and 5 in control, $+\mathrm{H}$ and $+\mathrm{PH}$ flasks. The nitrate concentrations decreased from 30 to $18 \mu \mathrm{mol} \mathrm{l}^{-1}$ in the $+\mathrm{N}$ flasks during the experiment. Phosphate concentrations were near or below the detection limit $\left(0.02 \mu \mathrm{mol} \mathrm{l}^{-1}\right)$ in control, $+\mathrm{N}$ and $+\mathrm{H}$ flasks during the whole experiment. In the $+\mathrm{P}$ flasks, the phosphate concentrations decreased from 5.0 to $2.6 \mu \mathrm{mol}^{-1}$ during the experiment. In the $+\mathrm{PH}$ flasks, phosphate concentrations decreased at the same rate as in the + P-flasks, after the addition of $5 \mu \mathrm{mol} \mathrm{l^{-1 }}$ phosphate on Day 6. Silicate concentration increased in the flasks throughout the whole experiment, probably due to silicon dissolving from the walls of the glass flasks, and was over $30 \mu \mathrm{mol} 1^{-1}$ at the end of the experiment.

\section{Chlorophyll a}

The chlorophyll a concentration increased in all flasks during the first $4 \mathrm{~d}$ of the experiment (Fig. 2). In the $+\mathrm{H}$ and the $+\mathrm{PH}$ flasks there was a lag phase of $1 \mathrm{~d}$ before chlorophyll concentrations started to increase. The control and $+P$ flasks then reached a peak value of 3 to $4 \mu \mathrm{g} \mathrm{l}^{-1}$ chlorophyll $a$ while in the $+\mathrm{N}$ flasks growth continued for about 3 more days until the chlorophyll a concentration was about $5 \mu \mathrm{gl}^{-1}$. In the $+\mathrm{H}$ and $+\mathrm{PH}$ flasks, the chlorophyll a concentration continued to increase until Days 7 and 8 of the experiment, reaching a concentration of about 6 to $7 \mu \mathrm{g} \mathrm{l}^{-1}$. The chlorophyll a concentrations were significantly higher in the $+\mathrm{H}$ and $+\mathrm{PH}$ flasks than in the control flasks from Day 5 to 9 ( $\mathrm{p}<0.05$, Mann-Whitney $U$-test $)$

\section{Primary production}

The mean carbon fixation values in the control and $+\mathrm{P}$ flasks were between 2 and $6 \mathrm{mg} \mathrm{C} \mathrm{m} \mathrm{m}^{-3} \mathrm{~h}^{-1}$ during the experiment. The carbon fixation in the $+\mathrm{N},+\mathrm{H}$ and $+\mathrm{PH}$ flasks reached significantly higher values 6 to $\left.13 \mathrm{mg} \mathrm{C} \mathrm{m} \mathrm{m}^{-3} \mathrm{~h}^{-1}\right)$ than the controls on Day $5(\mathrm{p}<0.05$, 

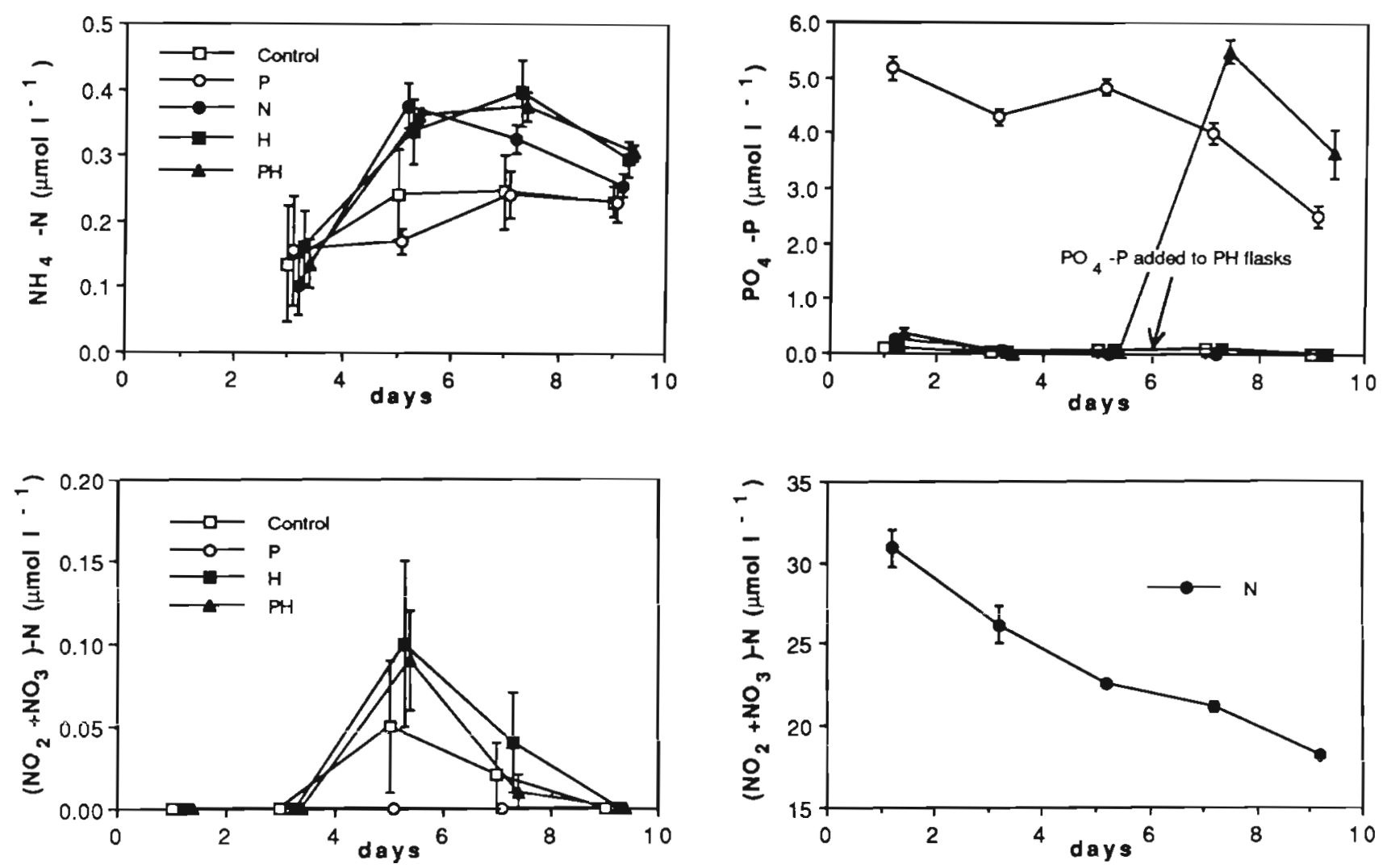

Fig. 1. Changes in nutrient concentrations (ammonium, nitrate+nitrite and phosphate) in response to the different initial additions. Treatments were $\mathrm{C}_{1}$ controls (no additions, except trace metals, iron and vitamins), $\mathrm{P}$-addition $\left(\mathrm{K}_{2} \mathrm{HPO}_{4}\right.$ to give a concentration of $5 \mu \mathrm{mol} \mathrm{l}^{-1}$ ), $\mathrm{N}$-addition $\left(\mathrm{NaNO}_{3}\right.$ to give a concentration of $30 \mu \mathrm{mol} \mathrm{l}^{-1}$ ), $\mathrm{H}$-addition (humic substances, gave a concentration of $4.3 \mathrm{mg} \mathrm{l^{-1 }}$ as DOC) PH-addition (humic substances as in $\mathrm{H}_{\text {plus }} \mathrm{K}_{2} \mathrm{HPO}_{4}$ as in P-addition on Day 6 of the experiment). The initial concentration of ammonium was $1.6 \mu \mathrm{mol} \mathrm{l}^{-1}$, which has been omitted in the figure. Error bars denote $\pm \mathrm{SD}$ of 4 replicates

Mann-Whitney $U$-test) (Fig. 3). After the addition of $5 \mu \mathrm{mol} \mathrm{l}^{-1}$ phosphate, the primary production in the $+\mathrm{PH}$ flasks became significantly higher than in the $+\mathrm{H}$ flasks ( $p<0.05$, Mann-Whitney $U$-test).

\section{Alkaline phosphatase activity}

Alkaline phosphatase activity was undetectable on Day 1 , became just detectable ( $>0.5 \mathrm{nmol} \mathrm{P}{ }^{-1} \mathrm{~min}^{-1}$ ) on Day 2 and increased after this in all flasks except the $+P$ flasks (Fig. 4). The highest activities were reached in the $+\mathrm{N}$, control and the $+\mathrm{H}$ flasks on Day 8 , indicating a shortage of inorganic phosphorus relative to the availability of inorganic nitrogen.

\section{Dissolved organic carbon}

The mean initial concentration of DOC was $7.2 \mathrm{mg}$ $1^{-1}$ in the control flasks (Fig. 5). When humic substances were added, the concentration of DOC in the
$+\mathrm{H}$ and $+\mathrm{PH}$ flasks increased to $11.6 \mathrm{mg} \mathrm{l}^{-1}$. The amount of humic substances added thus corresponded to $4.3 \mathrm{mg} \mathrm{l}^{-1}$ DOC. During the experiment there was a continuous decrease in DOC. The DOC concentration decreased in all treatments by approximately $3.0 \mathrm{mg}$ $\mathrm{l}^{-1}$ during the first $5 \mathrm{~d}$ of the experiment. The concentration of DOC in flasks to which humic acids were added continued to decrease during the last $4 \mathrm{~d}$ of the experiment (from approximately 9 to $8 \mathrm{mg} \mathrm{l}^{-1}$ ), while there was a minor increase in the controls and the flasks to which phosphate or nitrate was added (from approximately 4.5 to $5.5 \mathrm{mg}^{-1}$ ).

\section{Bacterial numbers}

The initial concentration of bacteria in the flasks was approximately $0.1 \times 10^{6}$ cells $\mathrm{ml}^{-1}$ (Fig. 6). The number of bacteria started to increase $2 \mathrm{~d}$ after the start of the experiment and there was a similar increase in control, $+P$ and $+N$ flasks where bacterial numbers were between 1.0 and $1.5 \times 10^{6}$ cells $\mathrm{ml}^{-1}$ on Day 9 of the 
experiment. In the $+\mathrm{H}$ and $+\mathrm{PH}$ flasks, the bacterial numbers became significantly higher than in the control flasks from Day 5 onwards $(p<0.05$, MannWhitney $U$-test) and had reached between 2.0 and $2.5 \times 10^{6}$ cells $\mathrm{ml}^{-1}$ by Day 9 of the experiment

\section{Phytoplankton numbers, growth rates and carbon content}

Counting phytoplankton samples fixed with Lugol's solution makes it difficult to distinguish between heterotrophic and autotrophic nanoflagellates. The nanoflagellates in our phytoplankton samples were dominated by autotrophic forms such as different prymnesiophyceans and photosynthetic cryptomonads, and we have used the terms 'flagellates $<3 \mu \mathrm{m}$, 3-6 $\mu \mathrm{m}$ and $6-10 \mu \mathrm{m}$ ' for these categories.

The initial phytoplankton community was dominated by all 3 size-classes of flagellates and the dinoflagellate Prorocentrum micans. These phytoplankton constituted more than $97 \%$ of the total phytoplankton carbon (Fig. 7). During the first $5 \mathrm{~d}$ of the experiment, total phytoplankton carbon increased from 21 to $89 \mu \mathrm{g}$ $\mathrm{Cl}^{-1}$ in the controls, while a higher increase occurred in the flasks to which phosphate, nitrate and humic compounds were added (to 115,140 and $148 \mu \mathrm{g} \mathrm{Cl}^{-1}$ respectively). Cell numbers were significantly higher for Nitzschia longissima, Chaetoceros sp. and P. micans in the humus treatments than in the controls on Day 5 ( $\mathrm{p}<0.05$, Mann-Whitney $U$-test) (Table 1). For $P$. micans the cell numbers were also significantly higher in the $+\mathrm{P}$ and $+\mathrm{N}$ treatments.

Growth rates for the diatoms Nitzschia longissima and Chaetoceros sp., flagellates $(3-6 \mu \mathrm{m})$ and oligotrich ciliates were significantly higher in the humus treatments than in the controls on Day 5 (Table 2). Between Days 5 and 9 of the experiment, there was an increase in small flagellates and diatoms in all treatments. After phosphate was added to the $+\mathrm{PH}$ flasks on Day 6 , there was an increase in chlorophyll $a$ in these flasks compared to the others. This increase was mainly due to an increase in cell numbers of diatoms and small flagellates.

\section{Protozooplankton}

In the initial water, there were approximately 0.1 oligotrich ciliates $\mathrm{ml}^{-1}$ (mainly Lohmanniella spp.). Tintinnids occurred at a density of approximately
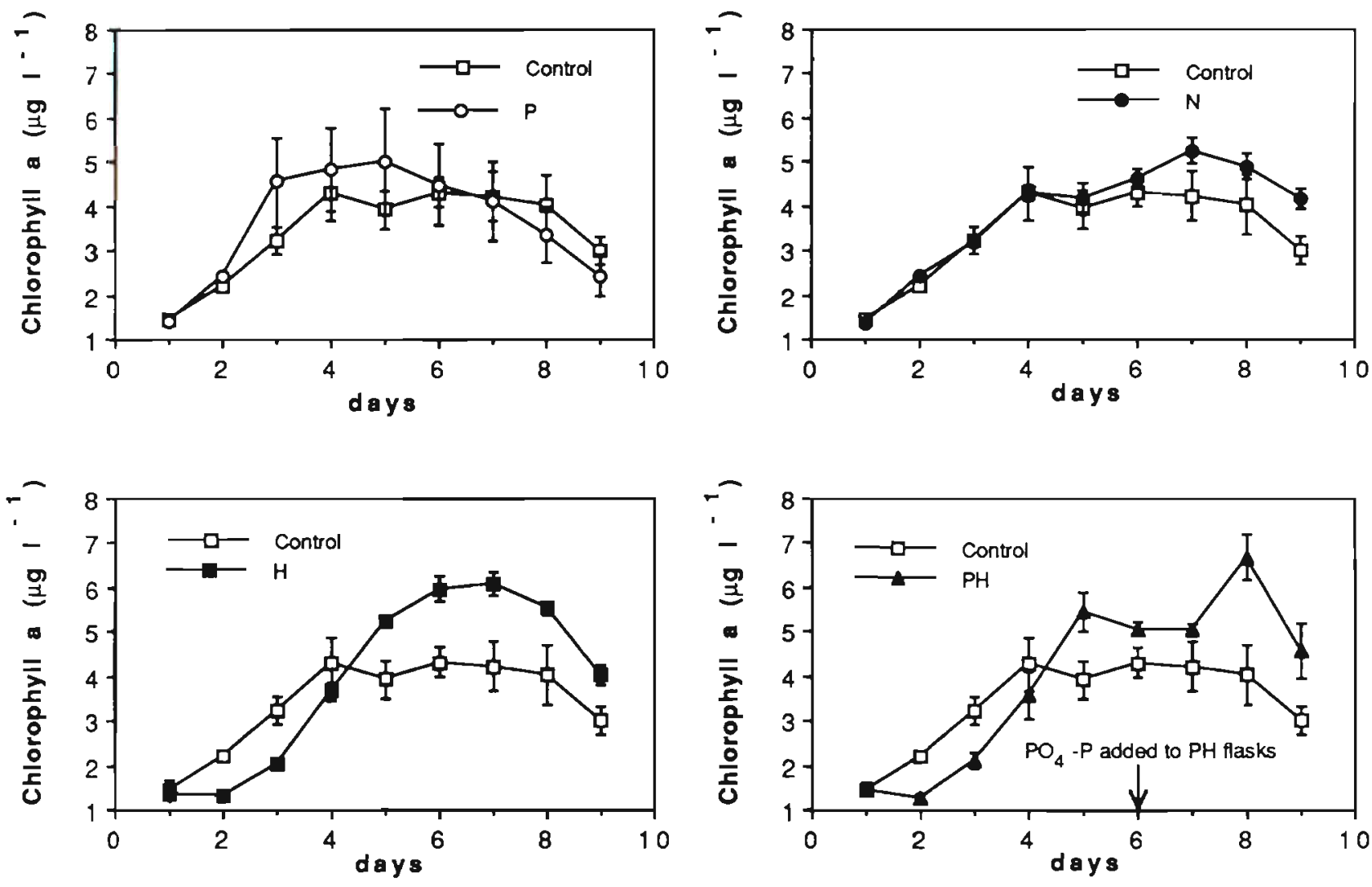

Fig. 2. Changes in chlorophyll $a$ in response to the different additions. Treatments as in Fig. 1 . Error bars denote \pm SD of 4 replicates 

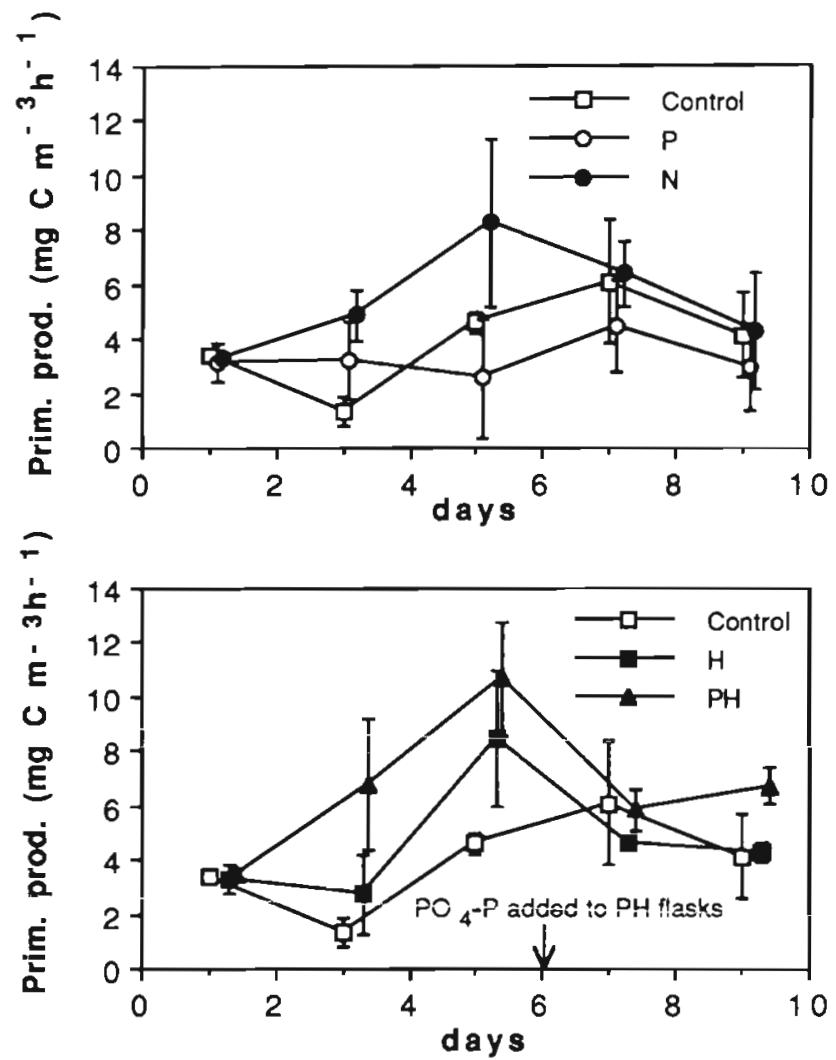

Fig. 3. Changes in primary production in response to the different additions. Treatments as in Fig. 1. Error bars denote $\pm \mathrm{SD}$ of 4 replicates

0.2 cells $\mathrm{ml}^{-1}$ and the dominant genera were Tintinnus sp., Tintinnopsis sp. and Coxliella sp. The numbers of oligotrich ciliates and tintinnids were significantly higher in the $+\mathrm{H}$ flasks than in the controls on Day 5 ( $\mathrm{p}<0.05$, Mann-Whitney $U$-test) (Table 1 ). Growth rates for oligotrich ciliates were also significantly higher in the treatments to which humic substances were added than in the controls (Table 2).

\section{DISCUSSION}

The results from this experiment show that addition of natural humic substances isolated from river water stimulates the growth and biomass formation of a coastal phytoplankton community. Bacterial numbers and numbers of ciliates were also increased by the addition of humic substances. Earlier investigations have shown that phytoplankton biomass formation can be stimulated by the addition of humic substances (Prakash \& Rashid 1968, Prakash et al, 1973, Gedziorowska \& Plinski 1986, Carlsson \& Granéli 1993). This growth stimulating effect has generally been attributed to the ability of humic substances to act as chelators, making elements such as iron available to phytoplankton (Ingle \& Martin 1971), or binding toxic trace metals (Mackey 1984). However, organic complexation of trace metals is also considered to make trace metals potentially unavailable for uptake by phytoplankton (Bruland et al. 1991).

The humic substances we added to our experimental system might have worked both as potential carriers of trace metals that were isolated together with the humic compounds from the river water and as potential chelators of trace metals present in the seawater we used. We therefore added a substantial surplus of iron and trace metals, together with the chelator EDTA, to all treatments in order to minimize the risk of limitation of trace metals in the flasks. The higher accumulation of phytoplankton biomass produced in the humic treatments compared with the controls cannot therefore be attributed to some potentially limiting trace metal added together with the humic substances.

The method we have used for extraction of humic compounds from river water is recommended by the International Humic Substances Society (IHSS). It is regarded, at present, as the most efficient method to extract humic compounds from water (Aiken 1988).
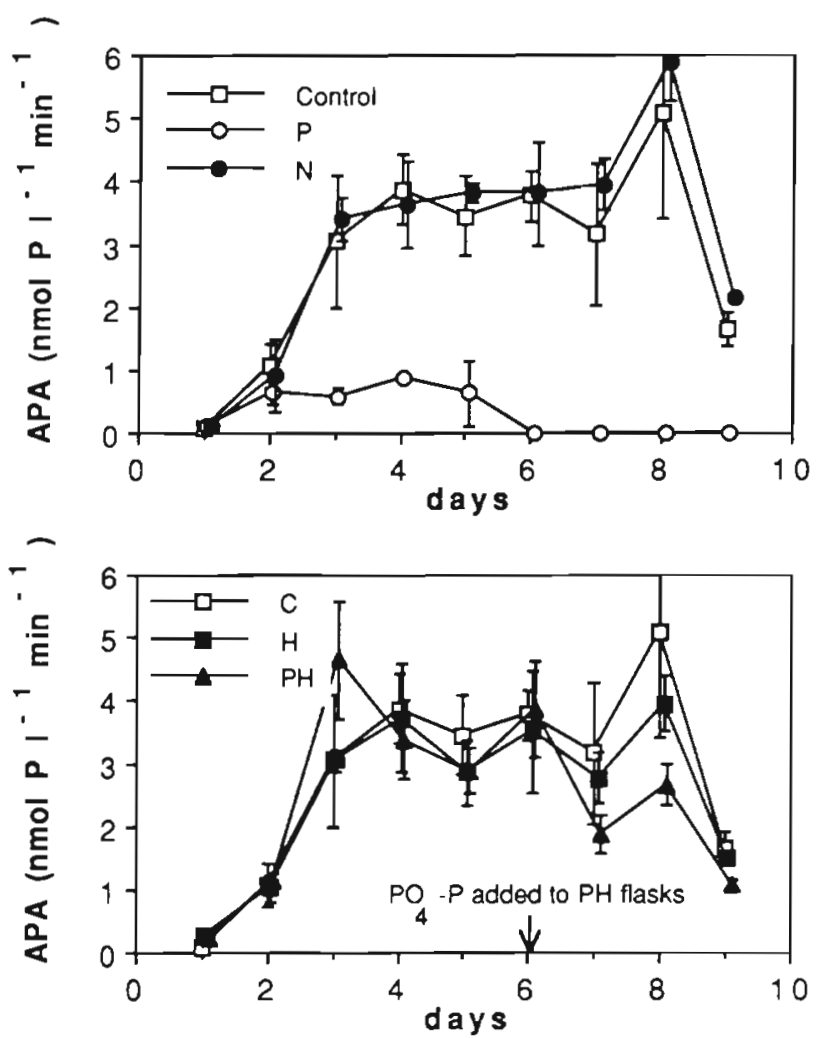

Fig. 4. Changes in alkaline phosphatase activity (APA) in response to the different additions. Treatments as in Fig. 1. Error bars denote $\pm \mathrm{SD}$ of 4 replicates 

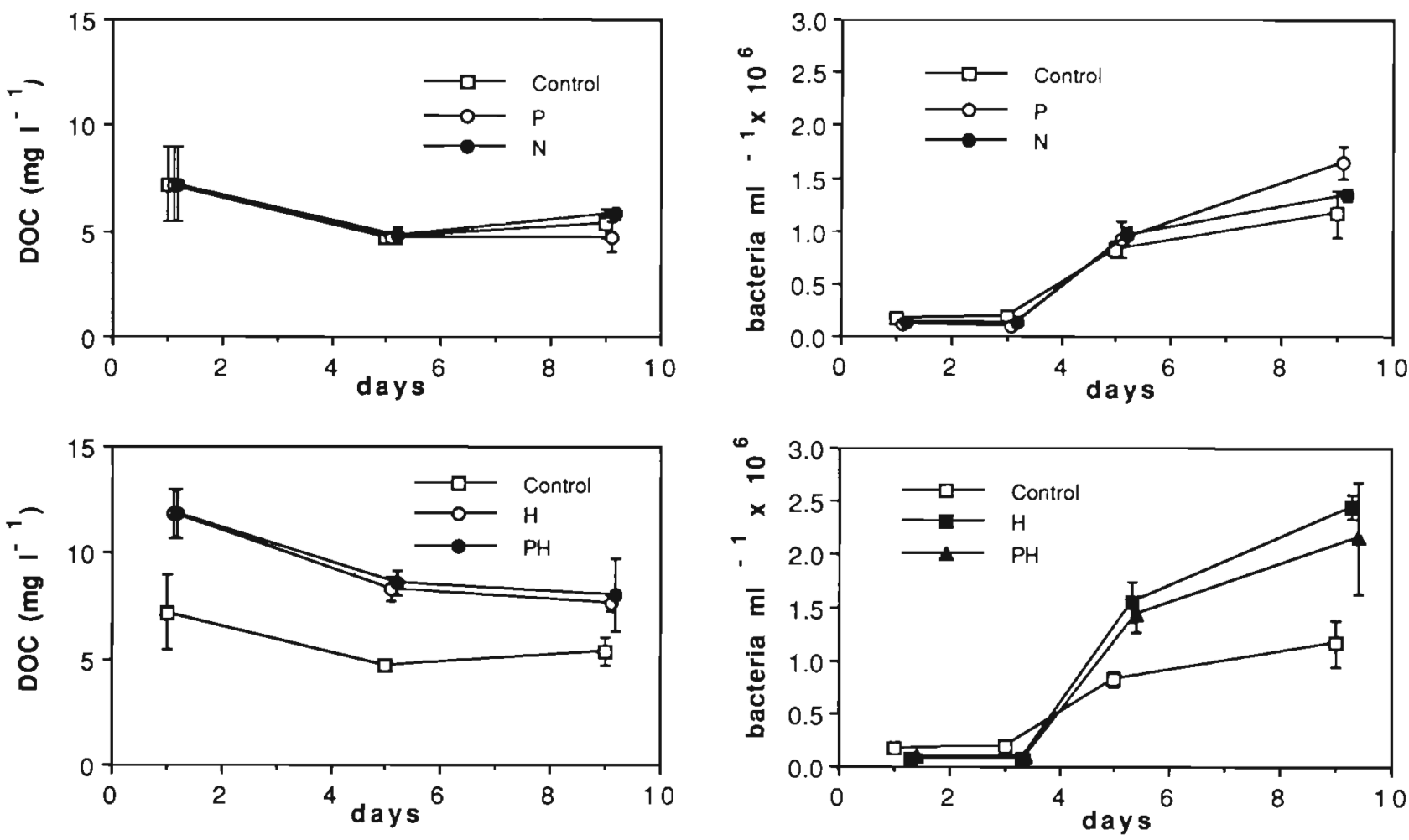

Fig. 5. Changes in dissolved organic carbon (DOC) in response to the different additions. Treatments as in Fig. 1 Error bars denote \pm SD of 4 replicates

Fig. 6. Changes in bacterial abundance in response to the different additions. Treatments as in Fig. 1. Error bars denote $\pm \mathrm{SD}$ of 4 replicates

The isolation process, however, almost certainly causes some alterations of the isolated humic substances such as hydrolysis of some organic matter caused by the elution process with $\mathrm{NaOH}$ (Liao et al.

1982, Bowles et al. 1989). Thus, the chemical properties of the humic substances we used in this experiment have, to some degree, inevitably been altered during the isolation process. In order to minimize the

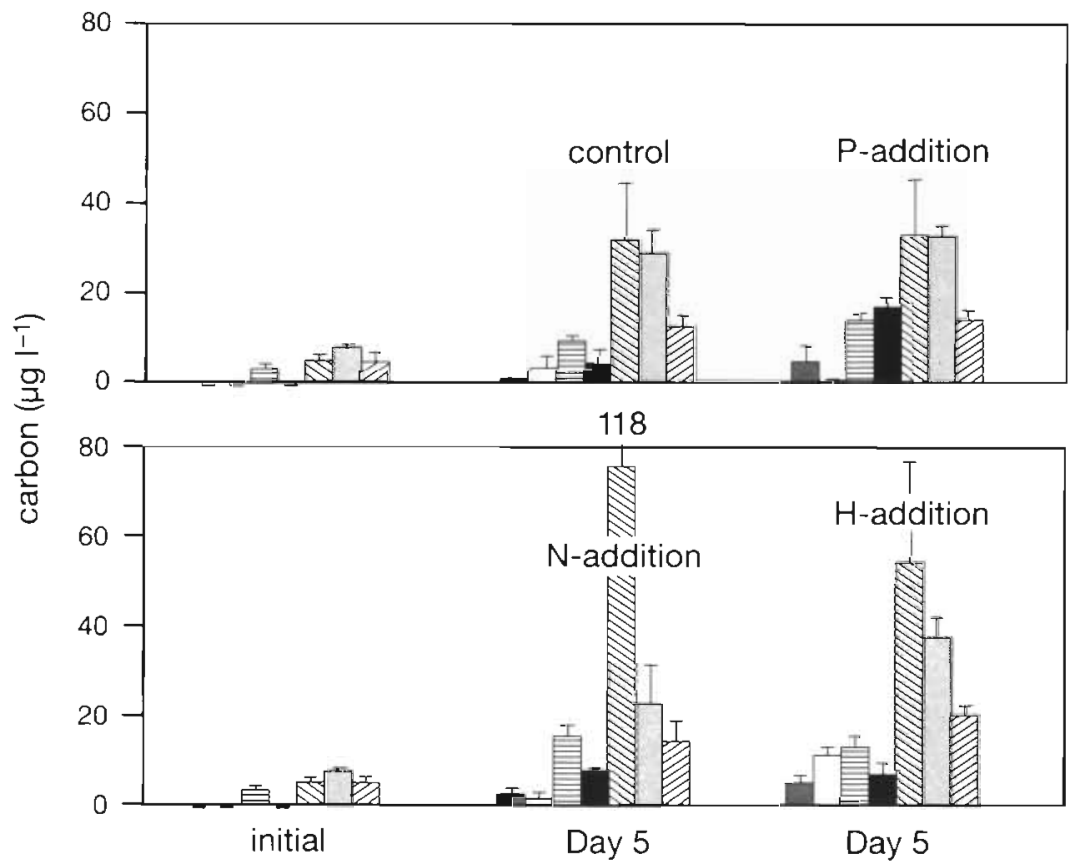

Nitzschia longissima

$\square$ Chaetoceros sp.

目 Prorocentrum micans

- Gyrodinium/Gymnodinium sp.

$\$$ flagellates $6-10 \mu \mathrm{m}$

$\square$ flagellates $3-6 \mu \mathrm{m}$

flagellates $<3 \mu \mathrm{m}$

Fig. 7. Contribution of dominant phytoplankton taxa to total biomass (as $\mu \mathrm{g}$ carbon $1^{-1}$, calculated by plasma/cell volume multiplied by factors according to Smetacek 1975 and Strathmann 1967) on the initial day and Day 5 of the experiment. Each value is mean of 4 replicates. Error bars denote $\pm S D$ of 4 replicates 
Table 1. Cell numbers (cells $\mathrm{ml}^{-1}$ ) for the dominant groups of the plankton in the different treatments on Day 1 and 5 of the experiment. Values are means of 4 replicates \pm standard deviation. The $+\mathrm{PH}$ treatment is omitted, since the $\mathrm{P}$-additions to these flasks were made on Day 6

\begin{tabular}{|c|c|c|c|c|c|}
\hline & Day 1 & Day 5 & $\begin{array}{c}\text { Treatment } \\
+\mathrm{P} \\
\text { Day } 5\end{array}$ & $\begin{array}{c}+\mathrm{N} \\
\text { Day } 5\end{array}$ & $\begin{array}{c}+\mathrm{H} \\
\text { Day } 5\end{array}$ \\
\hline Nitzschia longissima & $1.6 \pm 1.7$ & $24.4 \pm 17.9$ & $185 \pm 101$ & $67.4 \pm 60.3$ & $142 \pm 79$ \\
\hline Chaetoceros sp. & $0.1 \pm 0.1$ & $9.2 \pm 14.1$ & $2.7 \pm 2.2$ & $5.7 \pm 8.6$ & $43.8 \pm 9.3$ \\
\hline Leptocylindrus minimus & 0 & $9.1 \pm 2.8$ & $4.1 \pm 1.8$ & $3.1 \pm 1.8$ & $3.1 \pm 2.9$ \\
\hline Leptocylindrus danicus & $0.1 \pm 0.1$ & $4.2 \pm 1.1$ & $3.5 \pm 3.1$ & $1.7 \pm 1.3$ & $3.5 \pm 1.8$ \\
\hline Prorocentrum micans & $6.2 \pm 2.1$ & $16.9 \pm 4.6$ & $26.5 \pm 6.2$ & $30.3 \pm 5.5$ & $25.5 \pm 4.7$ \\
\hline Katodinium sp. & $0.3 \pm 0.2$ & $1.7 \pm 0.8$ & $0.8 \pm 0.2$ & $0.7 \pm 0.6$ & $2.5 \pm 1.3$ \\
\hline Gyrodinium/Gymnodinium sp. & 0 & $77.3 \pm 57.4$ & $193 \pm 180$ & $136 \pm 17$ & $88 \pm 97$ \\
\hline Flagellates $(6-10 \mu \mathrm{m})$ & $132 \pm 53$ & $920 \pm 369$ & $932 \pm 437$ & $2168 \pm 1211$ & $1554 \pm 810$ \\
\hline Flagellates $(3-6 \mu \mathrm{m})$ & $1232 \pm 95$ & $4774 \pm 985$ & $5400 \pm 642$ & $3796 \pm 1467$ & $6294 \pm 810$ \\
\hline Flagellates $(<3 \mu \mathrm{m})$ & $472 \pm 49$ & $1952 \pm 518$ & $2178 \pm 198$ & $1920 \pm 538$ & $2128 \pm 245$ \\
\hline Oligotrich ciliates & $0.1 \pm 0.1$ & $0.3 \pm 0.3$ & $0.8+0.4$ & $0.6 \pm 0.2$ & $1.3 \pm 0.6$ \\
\hline Tintinnids & $0.2 \pm 0.1$ & $0.6 \pm 0.6$ & $2.6 \pm 1.2$ & $1.4 \pm 0.6$ & $2.5 \pm 0.2$ \\
\hline
\end{tabular}

alkaline hydrolysis reactions, we directly acidified the eluate to $\mathrm{pH} 2.5$.

Humic compounds are often considered to represent the fraction of organic matter from which all easily available energy sources have been exhausted (Rashid 1985). The residual material is therefore assumed to be of little use as a substrate and with no nutritional value for the microbial population. However, some studies have shown that a high microbial activity can be main- tained with allochthonous dissolved organic carbon or humic substances as the energy source (Tranvik 1989 , Moran \& Hodson 1990).

DOC occuring in marine waters is mainly produced by phytoplankton and easily assimilated by bacteria compared to river DOC in which allochthonous compounds that are more refractory constitute a larger proportion of the DOC pool (Hobbie 1988). However, in coastal waters the allochthonous DOC emanating from

Table 2. Growth rates (djv. $\mathrm{d}^{-1}$ ) for the dominant groups of the plankton. Values are mean of 4 replicates \pm standard deviation. Growth rates were calculated according to the formula: div. $\mathrm{d}^{-1}=\left(\log _{2} N-\log _{2} N_{0}\right) / t$, where $N_{0}=$ cell numbers on Day $1, N=$ cell numbers on Day 5 and $t=4 \mathrm{~d}$. The Mann-Whitney $U$-test was used to compare the growth rates in the different treatments with the controls. As in Table 1, the $+\mathrm{PH}$ treatment is omitted

\begin{tabular}{|c|c|c|c|c|}
\hline & \multicolumn{4}{|c|}{ Treatment } \\
\hline & $\mathrm{C}$ & $+\mathrm{P}$ & $+\mathrm{N}$ & $+\mathrm{H}$ \\
\hline Nitzschia longissima & $0.9 \pm 0.5$ & $1.7 \pm 0.5$ & $1.2 \pm 0.7$ & $1.6 \pm 0.3^{\circ}$ \\
\hline Chaetoceros sp. & $1.5 \pm 0.4$ & $1.3 \pm 0.5$ & $1.3 \pm 0.5$ & $2.3 \pm 0.4^{\circ}$ \\
\hline Leptocylindrus minimus & $2.0 \pm 0.4$ & $1.7 \pm 0.6$ & $1.5 \pm 0.6$ & $1.8 \pm 0.4$ \\
\hline Leptocylindrus danicus & $1.8 \pm 0.5$ & $1.6 \pm 0.7$ & $1.4 \pm 0.6$ & $1.6 \pm 0.4$ \\
\hline Prorocentrum micans & $0.4 \pm 0.2$ & $0.5 \pm 0.2$ & $0.6 \pm 0.2$ & $0.5 \pm 0.1$ \\
\hline Katodinium sp. & $0.6 \pm 0.1$ & $0.3 \pm 0.2$ & $0.4 \pm 0.2$ & $0.7 \pm 0.1$ \\
\hline Gyrodinium /Gymnodinium sp. & $3.2 \pm 0.3$ & $3.7 \pm 0.1$ & $3.4 \pm 0.0$ & $3.4 \pm 0.2$ \\
\hline Flagellates $(6-10 \mu \mathrm{m})$ & $0.7 \pm 0.2$ & $0.7 \pm 0.2$ & $1.0 \pm 0.1$ & $0.9 \pm 0.2$ \\
\hline Flagellates $(3-6 \mu \mathrm{m})$ & $0.5 \pm 0.1$ & $0.5 \pm 0.0$ & $0.4 \pm 0.1$ & $0.6 \pm 0.1^{\circ}$ \\
\hline Flagellates $(<3 \mu \mathrm{m})$ & $0.5 \pm 0.1$ & $0.6 \pm 0.0$ & $0.5 \pm 0.1$ & $0.6 \pm 0.1$ \\
\hline Oligotrich ciliates & $0.1 \pm 0.7$ & $0.9 \pm 0.5$ & $0.8 \pm 0.4$ & $1.1 \pm 0.5^{*}$ \\
\hline Tintinnids & $0.4 \pm 1.3$ & $1.1 \pm 0.4$ & $0.9 \pm 0.7$ & $1.1 \pm 0.6$ \\
\hline
\end{tabular}


river waters can presumably make up a substantial part of the total DOC pool. The addition of $4.3 \mathrm{mg} \mathrm{l}^{-1}$ of HS (measured as DOC) was not a large addition of an easily processed bacterial substrate, since it was composed of humic compounds isolated from river water, and the mean initial concentration of DOC in the coastal water we used was $7.2 \mathrm{mg} \mathrm{l}^{-1}$ in the control flasks

The increasing bacterial numbers between Days 3 and 5 indicate either that bacteria could utilize some available substrate (probably DOC from the growing phytoplankton community and the added humic substances) or that grazing pressure on bacteria from heterotrophic nanoflagellates was lowered. Since the flagellates in the 3 counted size ranges had relatively high growth rates, a lowered grazing pressure on bacteria by heterotrophic flagellates is a more unlikely explanation. The removal of larger zooplankton by prefiltration of the water through a $150 \mu \mathrm{m}$ net would have decreased the grazing pressure on the heterotrophic flagellates by larger zooplankton thus giving a higher grazing pressure on bacteria instead of lowering it. The increase in chlorophyll a concentration in all flasks, coinciding with the increase in bacterial numbers in all flasks, is also an indication that this was due to release of DOC from the growing phytoplankton community. The higher increase in bacterial numbers in the flasks where HS were added, compared with the other flasks, means that HS also may have been utilized by bacteria as a substrate. The concentration of DOC also decreased in both the control flasks and the flasks to which HS were added during the period of increasing chlorophyll a concentrations, probably due to bacterial uptake and utilization of DOC.

Humic substances contain some nitrogen, but it is far from clear how this nitrogen is associated with the humic material (Schnitzer 1985). According to Schnitzer (1985) there may be 2 types of nitrogen components in the humic material: one group in which the nitrogen compounds have distinct chemical characteristics (such as amino acids, purines, etc.) and one group where the nitrogen has become an integral part of the humic substances. Approximately $75 \%$ of the nitrogen associated with humic substances belongs to the first group and is only loosely held or adsorbed (Schnitzer 1985), and this nitrogen may thus be available for biological processes such as bacterial or algal uptake.

About 25 to $40 \%$ of the nitrogen in humic compounds isolated from soil is bound to amino acids (Khan \& Sowden 1971). If the nitrogen present in the added humic substances became available for phytoplankton in our experiment, this could explain the higher biomass accumulation in the flasks to which HS were added.
There is a possibility that nitrogen can be removed from its binding sites in the humic compounds by microbial activity (Müller-Wegener 1988). Photodegradation of humic compounds by UV-radiation into products with lower molecular weight may also be an important process to facilitate bacterial degradation of HS (Amador et al. 1989, Kieber et al. 1990).

In our experiment, bacteria could have been mineralizing the nitrogen bound to HS or photodegradation products of HS (since about $20 \%$ of the UV-B radiation could pass the Pyrex glass flasks), and ammonium released by bacteria might subsequently have been taken up by the phytoplankton. However, when the $\mathrm{C}: \mathrm{N}$ quota of the organic matter used by the bacteria is $>10$, an uptake of $\mathrm{N}$ and not a mineralization will take place (Billen 1984). It is thus plausible that the nitrogen in the humic compounds used in this experiment (C:N = 49) might have been assimilated by bacteria. The way the nitrogen then becomes available to the phytoplankton is probably through the grazing activity of heterotrophic flagellates and ciliates on bacteria, and grazing of tintinnids and ciliates on heterotrophic flagellates which will generate ammonium as an excretory product. The release of ammonium by this grazing activity is indicated by the increasing ammonium concentrations during the experiment. The ammonium concentrations are low, but there could have been a rapid flux of ammonium between excretion and uptake.

The initial concentration of inorganic nitrogen (mainly as ammonium) and phosphate was enough to increase the phytoplankton biomass from approximately 1.5 to $4 \mu^{-1}$ of chlorophyll $a$ in the control flasks. During the first $5 \mathrm{~d}$ of the experiment, the largest increase in chlorophyll a was in the flasks to which phosphate was added. This indicates that there was a shortage of available inorganic phosphorus for phytoplankton growth in the initial water. Alkaline phosphatase activity increased in all treatments except those where phosphate was added during the experiment suggesting an inorganic phosphorus deficiency (Elgavish et al. 1982, Chróst \& Overbeck 1987). The increase in alkaline phosphatase activity could have been caused by both phytoplankton and bacterial phosphatases, since it has been shown that bacterial alkaline phosphatase activity can be significant (Chróst \& Overbeck 1987).

The increase in chlorophyll a between Days 6 and 8 in the $+\mathrm{PH}$ flasks after the addition of phosphate coincided with a decrease in alkaline phosphatase activity and a utilization of the added phosphate, suggesting that phytoplankton biomass formation had become phosphorus limited in the flasks to which humic substances were added. This is consistent with the findings of Brassard \& Auclair (1984) and Francko (1986) 
that humic substances stimulated phosphate uptake by phytoplankton. The significant increase in primary production in the $+\mathrm{PH}$ flasks, compared with controls, after the addition of phosphate, also indicates that the phytoplankton had access to a nitrogen source, probably humic bound nitrogen.

Some authors have shown a negative influence of HS on primary production and chlorophyll a concentrations in limnic systems (Jackson \& Hecky 1980, Guildford et al. 1987). Jackson \& Hecky (1980), in a correlation study of river systems in Canada, observed that primary production was inversely related to DOC concentrations. They suggested that HS acted by reducing iron availability to phytoplankton through the formation of humic-iron-phosphate complexes. Guildford et al. (1987) conducted a long-term limnocorral experiment in which the added HS (moss and peat material) depressed chlorophyll a concentrations and primary production compared to control treatments. Their data show, however, that an initial elevation of dissolved phosphorus and nitrogen concentrations was evident in the HS treatments and that this was associated with higher chlorophyll a concentrations and higher primary production during the first 2 to $3 \mathrm{wk}$ of their experiment.

Problems concerning the divergent development of different processes in enclosed volumes compared with the in situ situation in pelagic systems constitute major drawbacks in experiments such as the one we have performed. There is therefore always some uncertainty as to whether this kind of experiment represents the natural conditions in an adequate way. Rapid depletion of ammonium, nitrate and phosphate occurred during the first $3 \mathrm{~d}$ of the experiment and nutrient deficiency must have been experienced by the phytoplankton, as suggested by the decreasing chlorophyll a concentrations after 5 to $8 \mathrm{~d}$, depending on the treatment. We have therefore chosen to base our major conclusions on the results from the first $5 \mathrm{~d}$ of the experiment. In our experiment, the major biological perturbation was the removal of larger grazers and the consequent absence of grazing as a loss factor for larger phytoplankton and the loss of regenerated nutrients from large zooplankton. This might have had some important effects on phytoplankton growth. The increase in chlorophyll a concentration seen in all flasks during the first $4 \mathrm{~d}$ could be an effect of a decreased grazing pressure during the incubation (Banse 1991). However, the higher maximum attained by chlorophyll a concentration and primary production in the flasks where HS were added, compared with the controls, shows that the addition of HS in addition to the removal of grazers stimulated algal growth.

The only statistically significant increases in growth rates that we found were for diatoms and flagellates in the HS treatments when compared with the controls. Dinoflagellates, which often seem to be less grazed than diatoms in situ (Huntley 1982, Granéli et al. 1989, Kim et al. 1989) but, on the other hand, also often have low growth rates, did not react as dramatically as diatoms and small flagellates to the HS addition. In situ, however, where loss rates due to grazing often are higher for diatoms and small flagellates than for dinoflagellates, the relative importance of rivertransported humic substances for dinoflagellate biomass formation would be larger (in a long-term perspective) than this experiment suggests.

An increase has been observed in the transport of humic material to Swedish coastal waters during the last 15 yr (Andersson et al. 1991, Forsberg 1992). According to Andersson et al. (1991) the increase in coloured substances in running waters has been more than $50 \%$ during the period 1972 to 1986 . Forsberg (1992) suggests that the main increase is due to increased precipitation during this period, but that 10 to $40 \%$ of the increase has been independent of the size of the discharge/runoff.

The nitrogen supply to the Kattegat doubled in the period from 1950 to 1980 and the main increase has taken place since 1970, while phosphorus supply has been constant or decreased slightly during this latter period (Andersson \& Rydberg 1988). As a consequence of this excessive nutrient loading, there are indications of an increase in primary production in the Kattegat (Nielsen \& Ertebjerg 1984, Edler 1986). Since 1980, heavy blooms of dinoflagellates (Ceratium spp.) have been occurring in the Kattegat on the Swedish west coast during autumn (Edler 1984, Granéli et al. 1989). These blooms have been followed by massive sedimentation of algal cells and oxygen deficiency over large sea floor areas. Considering that organic nitrogen is the dominant nitrogen fraction transported from forest ecosystems (Fleischer \& Stibe 1989), there is now a larger amount of organically bound nitrogen reaching coastal waters that to some extent can become available as a nutrient source for phytoplankton. It is therefore possible that there is a connection between the increase in river transported HS carrying organically bound nutrients and the reports of algal blooms and anoxic events in coastal areas of the Swedish west coast.

Acknowledgements. This study was supported by funds from the Swedish Natural Science Research Council (NFR), the Swedish Environmental Protection Agency, the Carl Trygger Foundation, Stockholm. The Royal Physiographic Society and the Crafoord Foundation, Lund, Sweden. We thank Anders Kullberg, Anders Hargeby and Robert C. Petersen Jr at the department of Limnology, University of Lund, Sweden, for helping us with the humic extraction and Bodil Andersson at 
the Kristineberg Marine Biological Station, Sweden, for helping us with the nutrient analyses. Wilhelm Granéli made valuable comments on the manuscript and Roger Finlay kindly corrected the English.

\section{LITERATURE CITED}

Ertebjerg-Nielsen, G., Bresta, A.-M. (1984). Guidelines for the measurement of phytoplankton primary production. The Baltic Marine Biologists (BMB) Publ. no. 1, 2nd edn

Aiken, G. R. (1988). A critical evaluation of the use of macroporous resins for the isolation of aquatic humic substances. In: Frimmel, F. H., Christman, R. F. (eds.) Humic substances and their role in the environment. John Wiley \& Sons Ltd, New York, p. 15-28

Amador, J. A., Alexander, M., Zika, R. G. (1989). Sequential photochemical and microbial degradation of organic molecules bound to humic acid. Appl. environ. Microbiol. 55: 2843-2849

Andersson, L., Rydberg, L. (1988). Trends in nutrient and oxygen conditions within the Kattegat: effects of local nutrient supply. Estuar. coast. Shelf Sci. 26: 559-579

Andersson, T., Nilsson, A.., Jansson, M. (1991). Coloured substances in Swedish lakes and rivers-temporal variation and regulating factors. In: Allard, B., Borén, H., Grimvall, A. (eds.) Humic substances in the aquatic and terrestrial environment. Lecture Notes in Earth Sciences, Vol. 33. Springer-Verlag, Berlin, p. 244-253

Banse, K. (1991). Rates of phytoplankton cell division in the field and in iron enrichment experiments. Limnol. Oceanogr. 36: 1886-1898

Barber, R. T. (1973). Organic ligands and phytoplankton growth in nutrient-rich seawater. In: Singer, P. C. (ed.) Trace metals and metal-organic interactions in natural waters. Ann Arbor Sci., Ann Arbor, p. 321-338

Billen, G. (1984). Heterotrophic utilization and regeneration of nitrogen. In: Hobbie, J. E., Williams, P. J. leB. (eds.) Heterotrophic activity in the sea. Plenum Press, New York, p. 313-355

Bowles, E. C., Antweiler, R. C., MacCarthy, P. (1989). Acidbase titration and hydrolysis of fulvic acid from the Suwannee River. In: Averett, R. C., Leenheer, J. A., McKnight, D. M., Thorn, K. A. (eds.) Humic substances in the Suwannee River, Georgia: interactions, properties, and proposed structures. U.S. Geological Survey, Denver, Colorado. Open File Report 87-557, p. 244-253

Brassard, P., Auclair, J. C. (1984). Orthophosphate uptake constants are mediated by the $10^{3}-10^{4}$ molecular weight fraction in Shield lake waters. Can. J. Fish. Aquat. Sci. 41; $166-173$

Bruland, K. W., Donat, J. R., Hutchins, D. A. (1991). Interactive influences of bioactive trace metals on biological production in oceanic waters. Limnol. Oceanogr. 36: 1555-1577

Carlsson, P., Granéli, E. (1993). Availability of humic bound nitrogen for coastal phytoplankton. Estuar. coast. Shelf Sci. 36: 433-447

Chróst, R. J., Overbeck, J. (1987). Kinetics of alkaline phosphatase activity and phosphate availability for phytoplankton and bacterioplankton in Lake Plußee (north German eutrophic lake). Microb. Ecol. 13: 229-248

Chróst, R. J., Münster, U., Rai, H., Albrecht, D., Witzel, P. K., Overbeck, J. (1989). Photosynthetic production and exoenzymatic degradation of organic matter in the euphotic zone of a eutrophic lake. J. Plankton Res. 11: 223-242
Edler, L. (ed.) (1979). Recommendations on methods for marine biological studies in the Baltic Sea - phytoplankton and chlorophyll. The Baltic Marine Biologists (BMB) Publ. no. 5

Edler, L. (1984). The Kattegat/Skagerrak. In: Rosenberg, R (ed.) Eutrophication of waters surrounding Sweden Swedish Environmental Protection Agency Report 3054 p. $71-108$

Edler, L. (1986). Production and nutrient uptake by algae Phytoplankton production in Laholm Bay. In: Rosenberg R. (ed.) The eutrophication situation in the Kattegat. Swedish Environmental Protection Agency Report 3272 p. 66-77 (in Swedish)

Elgavish, A., Halman, M., Berman, T. (1982). A comparative study of phosphorus utilization in batch cultures of Peridinium cinctum, Pediastrum duplex, and Cosmarium sp. from Lake Kinneret (Israel). Phycologia 21: 47-54

Fenchel, T., Blackburn, T. H. (1979). Bacteria and mineral cycling. Academic Press, London

Fleischer, S., Stibe, L. (1989). Agriculture kills marine fish in the $1980 \mathrm{~s}$. Who is responsible for fish kills in the year 2000? Ambio 6: 347-350

Forsberg, C. (1992). Will an increased greenhouse impact in Fennoscandia give rise to more humic and coloured lakes? Hydrobiol. 229: 51-58

Francko, D. A. (1986). Epilimnetic phosphorus cycling: influence of humic materials and iron on coexisting major mechanisms. Can. J. Fish. Aquat. Sci. 43: 302-310

Gedziorowska, D., Plinski, M. (1986). Influence of dissolved substances of humic type on the growth of phytoplankton communities. Ophelia, Suppl. $4: 335-338$

Geller, A. (1983). Degradability of dissolved organic lake water compounds in cultures of natural bacterial communities. Arch. Hydrobiol. 99: 60-79

Granéli, E., Edler, L., Gedziorowska., Nyman, U. (1985). Influence of humic and fulvic acids on Prorocentrum minimum (Pav.) J. Schiller. In: Anderson, D. M., White, A. W., Baden, D. G. (eds.) Toxic dinoflagellates. Elsevier Science Publishing Co., New York, p. 201-206

Granéli, E., Carlsson, P., Olsson, P., Sundström, B., Granéli, W., Lindahl, O. (1989). From anoxia to fish poisoning: the last ten years of phytoplankton blooms in Swedish marine waters. In: Cosper, E. M., Bricelj, V. M., Carpenter, E. J. (eds.) Novel phytoplankton blooms - causes and impacts of recurrent brown tides and other unusual blooms. Springer-Verlag, Berlin, p. 407-427

Guillard, R. R. L., Ryther, J. H. (1962). Studies of marine planktonic diatoms. I. Cyclotella nana Hustedt and Detonula confervacea (Cleve) Gran. Can. J. Microbiol. 8: 229-239

Guildford, S. J., Healy, F. P., Hecky, R. E. (1987). Depression of primary production by humic matter and suspended sediment in limnocorral experiments at southern Indian Lake, Northern Manitoba. Can. J. Fish. Aquat. Sci. 44: $1408-1417$

Hobbie, J. E. (1988). A comparison of the ecology of planktonic bacteria in fresh and salt water. Limnol. Oceanogr. 33: $750-764$

Huntley, M. E. (1982). Yellow water in La Jolla Bay, California, July 1980. II. Suppression of zooplankton grazing. J. exp. mar. Biol. Ecol. 63: 81-91

Ingle, R. M., Martin, D. F. (1971). Prediction of the Florida red tide by means of the iron index. Environ. Lett, 1: 69-74

Jackson, T. A., Hecky, R. E. (1980). Depression of primary productivity by humic matter in lake and reservoir waters of the boreal forest zone. Can. J. Fish. Aquat. Sci. 37 : $2300-2317$ 
Jeffrey, S. W., Humphrey, G. F. \{1975\}. New spectrophotometric equations for determining chlorophylls $a, b, c_{1}$ and $c_{2}$ in higher plants, algae and natural phytoplankton. Biochem. Physiol. Pflanz. 167: 191-194

Jones, R. I. (1992). The influence of humic substances on lacustrine planktonic food chains. Hydrobiol. 229: 73-91

Khan, S. U., Sowden, F. J. (1971). Distribution of nitrogen in the Black Solonetzic and Black Chernozemic soils of Alberta. Can. J. Soil Sci. 51: 185-193

Kieber, R. J., Zhou, X., Mopper, K. (1990). Formation of carbonyl compounds from UV-induced photodegradation of humic substances in natural waters: fate of riverine carbon in the sea. Limnol. Oceanogr. 35: 1503-1515

Kim, S. W., Yoon, Y. H., Onbé, T., Endo, T. (1989). Is grazing of marine cladocerans important for the occurrence of red tide? In: Okaichi, T., Anderson, D. M., Nemoto, T. (eds.) Red tides: biology, environmental science and toxicology. Elsevier Science Publishing Co., New York, p. $261-264$

Larsson, U., Hagström, $\AA$. (1979). Phytoplankton exudate release as an energy source for the growth of pelagic bacteria. Mar. Biol. 52: 199-206

Liao, W., Christman, R. F., Johnson, J. D., Millington, D. S. (1982). Structural characterization of aquatic humic material. Environ. Sci. Tech. 16: 97-106

Mackey, D. (1984). Trace metals and the productivity of shelf waters of North West Australia. Austral. J. mar. Freshwat. Res. 35: 505-516

Moran, M. A., Hodson, R. E. (1990). Bacterial production on humic and nonhumic components of dissolved organic carbon. Limnol. Oceanogr. 35:1744-1756

Müller-Wegener, U. (1988). Interaction of humic substances with biota. In: Frimmel, F. H., Christman, R. F. (eds.) Humic substances and their role in the environment. John Wiley \& Sons Ltd, Chichester, p. 179-192

Nielsen, A, Ertebjerg, G. (1984). Plankton blooms in Danish waters. Ophelia, Suppl. 3: 181-188

Paerl, H. W. (1988). Nuisance phytoplankton blooms in coastal, estuarine and inland waters. Limnol. Oceanogr. 33: $823-847$

Petersen, R. C. Jr, Hargeby, A., Kullberg, A. (1987). The biological importance of humic material in acidified waters. National Swedish Environmental Protection Board Report 3388

Petterson, K. (1979). Enzymatic determination of orthophosphate in natural waters. Int. Rev. ges. Hydrobiol. 64: 585-607

Porter, K. G., Feig, Y. S. (1980). The use of DAPI for identifying and counting aquatic microflora. Limnol. Oceanogr. 25: $943-948$

Prakash, A. (1971). Terrigenous organic matter and coastal phytoplankton fertility. In: Costlow, J. D. (ed.) Fertility of

This article was submitted to the editor the sea. Gordon and Breach, New York, p. 351-368

Prakash, A.. Rashid, M. A. (1968). Influence of humic substances on the growth of marine phytoplankton: dinoflagellates. Limnol. Oceanogr. 13: 598-606

Prakash, A., Rashid, M. A., Jensen, A., Subba Rao, D. V (1973). Influence of humic substances on the growth of marine phytoplankton: diatoms. Limnol. Oceanogr. 18: 516-524

Rashid, M. A. (1985). Geochemistry of marine humic compounds. Springer-Verlag, New York

Schnitzer, M. (1985). Nature of nitrogen in humic substances In: Aiken, G. R., Mcknight, D. M., Wershaw, R. L. (eds.) Humic substances in soil, sediment, and water. John Wiley \& Sons, New York, p. 303-328

Schöne, H. K, Schöne, A (1982). A weakly enriched sea-water medium for ecological studies on marine plankton algae, some examples of its application. Bot. Mar. 25: 117-122

Smetacek, V. (1975). Die Sukzession des Phytoplankton in der westlichen Kieler Bucht. Ph.D. thesis, Institut für Meereskunde, Kiel

Solórzano, L., Sharp, J. H. (1980). Determination of total dissolved nitrogen in natural waters. Limnol. Oceanogr. 25 $751-754$

Strathmann, R. R., (1967). Estimating the organic carbon content of phytoplankton from cell volume or plasma volume. Limnol. Oceanogr. 12: 411-418

Thurman, E M. (1985). Organic geochemistry of natural waters. Martinus Nijhoff/Dr W. Junk Publishers, Boston

Thurman, E. M., Malcolm, R. L. (1981). Preparative isolation of aquatic humic substances. Environ. Sci. Technol. 15: $463-466$

Toledo, A. P. P., D’Aquino, V. A., Tundisi, J. G. (1982). Influence of humic acid on growth and tolerance to cupric ions in Melosira italica (subsp. antarctica). Hydrobiol. 87: $247-254$

Tranvik, L. J. (1988). Availability of dissolved organic carbon for planktonic bacteria in oligotrophic lakes of differing humic content. Microb. Ecol. 16: 311-322

Tranvik, L. J. (1989). Bacterioplankton growth, grazing mortality and quantitative relationship to primary production in a humic and clearwater lake. J. Plankton Res. 11: $985-1000$

UNESCO (1983). Chemical methods for use in marine environmental monitoring. Intergovernmental Oceanographic Commission, Manuals and guides, no. 12

Utermöhl, H. (1958). Zur Vervollkommung der quantitativen Phytoplankton Methodik. Mitt. int, Ver. Limnol. 9: 1-38

Vadstein, O., Harkjerr, B. O., Jensen, A., Olsen, Y., Reinertsen, H. (1989). Cycling of organic carbon in the photic zone of a eutrophic lake with special reference to the heterotrophic bacteria. Limnol. Oceanogr. 34: 840-855

Manuscript first received: March 1, 1993

Revised version accepted: May 11, 1993 